\title{
Endobronchial Hamartoma
}

National Cancer Institute

\section{Source}

National Cancer Institute. Endobronchial Hamartoma. NCI Thesaurus. Code C5662.

A benign neoplasm that arises endobronchially. It is characterized by the presence of mesenchymal tissues admixed with entrapped respiratory epithelium. It presents with signs and symptoms of bronchial obstruction. Bronchoplastic resection is usually curative. Recurrence is very rare. 